\title{
Intravitreal bevacizumab therapy for idiophatic juxtafoveolar retinal telangiectasis associated with serous macular detachment
}

\author{
Tratamento com injeção intravítrea de bevacizumabe \\ para telangiectasia justafoveolar idiopática \\ associada a descolamento seroso macular
}

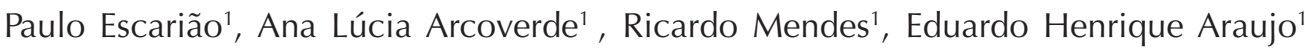

\begin{abstract}
The authors describe a 50-year-old woman with group 2 juxtafoveolar retinal telangiectasis and macular detachment treated with a single-dose of intravitreous bevacizumab injection. There was an improvement in her visual acuity, with a decrease in retinal thickness showed by the optical coherence tomography and fluorescein leakage in the angiography on follow-up visits. No adverse events were observed as a result of the treatment used. After one year of follow-up, the vision remained stable and macular detachment did not recur.

Keywords: Bevacizumab; Retinal telangiectasis; Macular detachment; Vascular endothelial growth factor, Intravitreal injection; Case reports

\section{RESUMO}

Os autores descrevem uma paciente do sexo feminino com 50 anos de idade portadora de telangiectasia justafoveolar idiopática tipo 2 , associada a descolamento macular e tratada com injeção intravítrea de bevacizumabe, dose única. Houve uma melhora da acuidade visual com diminuição da espessura retiniana documentada por tomografia de coerência óptica e angiografia fluoresceínica durante seu acompanhamento. Não observou-se efeitos adversos em consequência do tratamento. Após um ano de acompanhamento, sua visão permaneceu estável e o descolamento macular não recorreu.

Descritores: Bevacizumabe; Telangiectasia retiniana; Descolamento macular; Fator de crescimento derivado do endotélio; Injeção intravítrea; Relatos de casos
\end{abstract}

\footnotetext{
'Department of Retinal and Vitreous Diseases, Fundação Altino Ventura e Hospital de Olhos de Pernambuco - Recife (PE), Brazil.
}

This case was presented during the XXXII Meeting of the Retinal and Vitreous Brazilian Society in April, 2007.

The authors declare no conflicts of interest

Received for publication: 9/7/2012 - Accepted for publication: 22/9/2013

Rev Bras Oftalmol. 2014; 73 (1): 47-9 


\section{INTRODUCTION}

$\mathbf{I}$ diopathic juxtafoveolar telangiectasia (IJFRT) is characterized by dilated retinal capillaries, lacking a causative factor such as diabetic retinopathy, venous occlusion or inflammatory diseases. The term IJFRT was introduced by Gass and Oyakawa in $1982^{(1)}$ and subsequently, Gass and Blodi in 1993 established a classification dividing the cases in groups, subtypes and stages ${ }^{(2)}$. Yannuzzi et al. ${ }^{(3)}$ proposed in 2006 a new classification based on clinical and optical coherence tomography (OCT) findings.

According to Gass and Blodi classification, group 1 IJFRT is characterized by dilation of capillaries, aneurysms, leakage and minimal nonperfusion. There is no evidence of subretinal neovascularization development in the course of group 1 disease $^{(2,3)}$. Treatment with laser photocoagulation in telangiectasia areas can be performed and has safety and efficacy well established ${ }^{(4)}$.

In group 2 IJFRT, the disease is usually bilateral, there is no development of cystoid macular edema and subretinal new vessels can be found in late stages ${ }^{(3)}$ with, generally, poor final visual acuity ${ }^{(5)}$. Treatment with laser photocoagulation is not recommended for this group ${ }^{(2)}$. Alternative treatments, such as intravitreal injections of steroids and anti-angiogenic drugs have been suggested ${ }^{(6,7)}$.

The present study reports the 12-month changes on vision and on macular morphology in a patient with neurossensory macular detachment associated with idiopathic juxtafoveolar retinal telangiectasia that underwent a single bevacizumab injection.

\section{Case report}

A 50-year-old female was referred to the department of retinal and vitreous diseases of the Hospital de Olhos de Pernambuco (HOPE) in August 2006 complaining of blurred vision in her right eye for two months. The visual acuity was 20/ 60 in the right eye and 20/25 in the left eye. The biomicroscopy of the anterior segment was normal for both eyes. Intraocular pressure was 16 and $14 \mathrm{mmHg}$. The retinal examination revealed a gray-white appearance of the macular region 360 degrees from the fovea in the right eye (Figure 1A) and the same appearance temporally in the left eye.

Fluorescein angiography revealed progressive increased hyperfluorescence with leakage in the macular area in the right eye 360 degrees from the fovea (Figure 1B) and temporally, also less intense nasally in the right eye (Figure 1C).

An optic coherence tomography (OCT) was undertaken. The OCT showed intraretinal fluid, a neurossensory detachment without cystic spaces and foveal atrophy in the right eye. There was no sign of a choroidal neovascularization (Figure 1D). Less intraretinal fluid could be seen in the left eye and discontinuation of the inner/outer segment layer temporally to the fovea. No cystic spaces were seen (Figure 1E).

These findings are compatible with group 2, subtype A of Gass classification.

The patient received one intravitreal injection of $0.05 \mathrm{~mL}$ $(1.25 \mathrm{mg})$ of bevacizumab using topical anesthetic (4\% lidocaine gel) under sterile conditions (eyelid speculum and povidone iodine). Bevacizumab was injected into the vitreous cavity using a 30-gauge needle inserted through the pars plana. After the injection, central retinal artery perfusion was confirmed with indirect ophthalmoscopy. The patient was then instructed to instill one drop of ciprofloxacin $0.3 \%$ into the injected eye four times daily for 5 days after the procedure.

After 06 months of follow-up it was observed a fully regression of the subfoveal fluid and a decrease in the retinal thickness observed by the OCT (Figure 2A). The fluorescein angiography showed a decrease in leakage (Figure 2B). The visual acuity improved from $20 / 60$ to $20 / 30$ and the patient referred a decrease in the metamorphopsy.

After one year of follow-up, the vision remains stable in 20/30 and there is no sub-retinal fluid detected by OCT (Figure $2 \mathrm{C})$. There was an increase in the leakage detected by fluorescein angiography (Figure 2D).
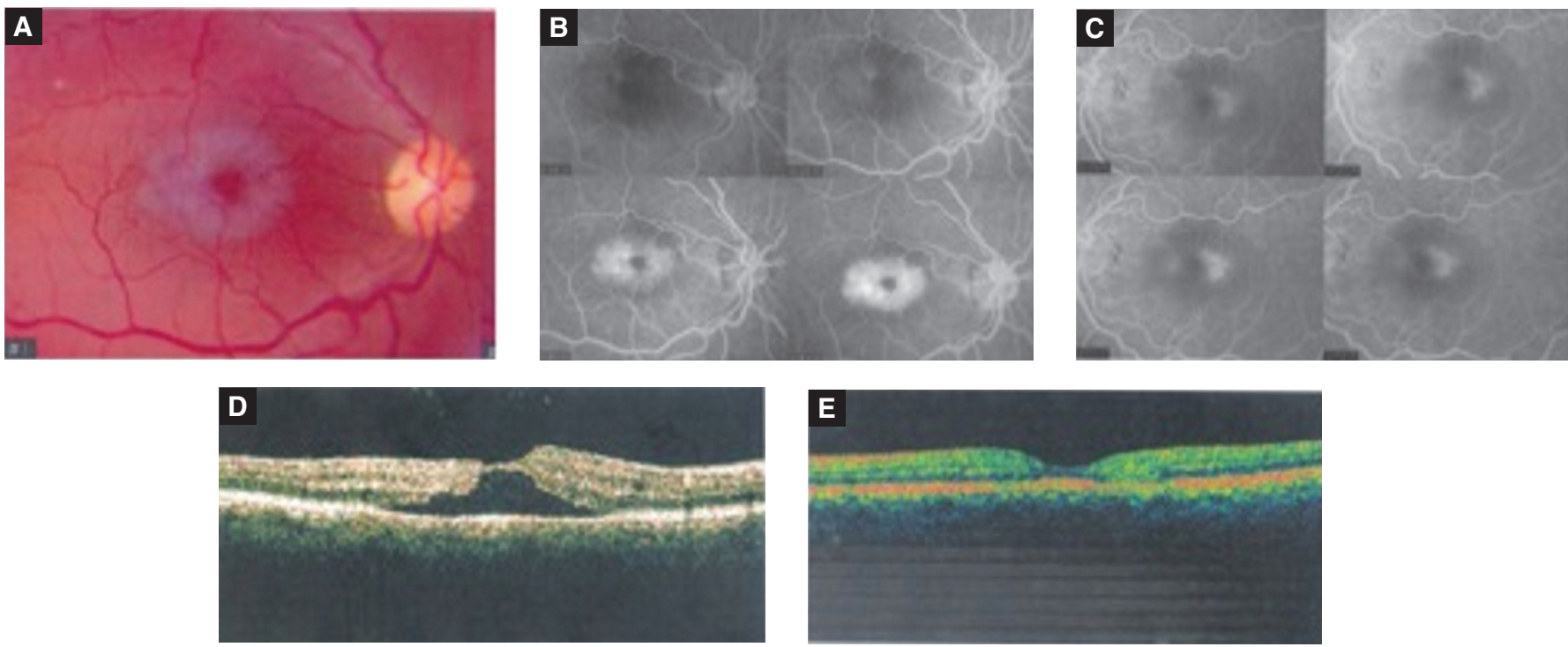

Figure 1 - (A) A gray-white appearance of the macular region in the right eye. (B) Fluorescein angiography of the right eye reveals severe leakage in the perifoveal area. (C) Fluorescein angiography of the left eye shows temporary leakage and less intense nasally to the fovea. (D) The OCT of the right eye reveals a foveal detachment, atrophy of the neurossensory retina in the foveal area and a retinal thickness. (E) In the left eye, there is a temporal discontinuation of the hyper-reflective layer to the fovea (inner segment/outer segment junction). No cystic spaces are observed 

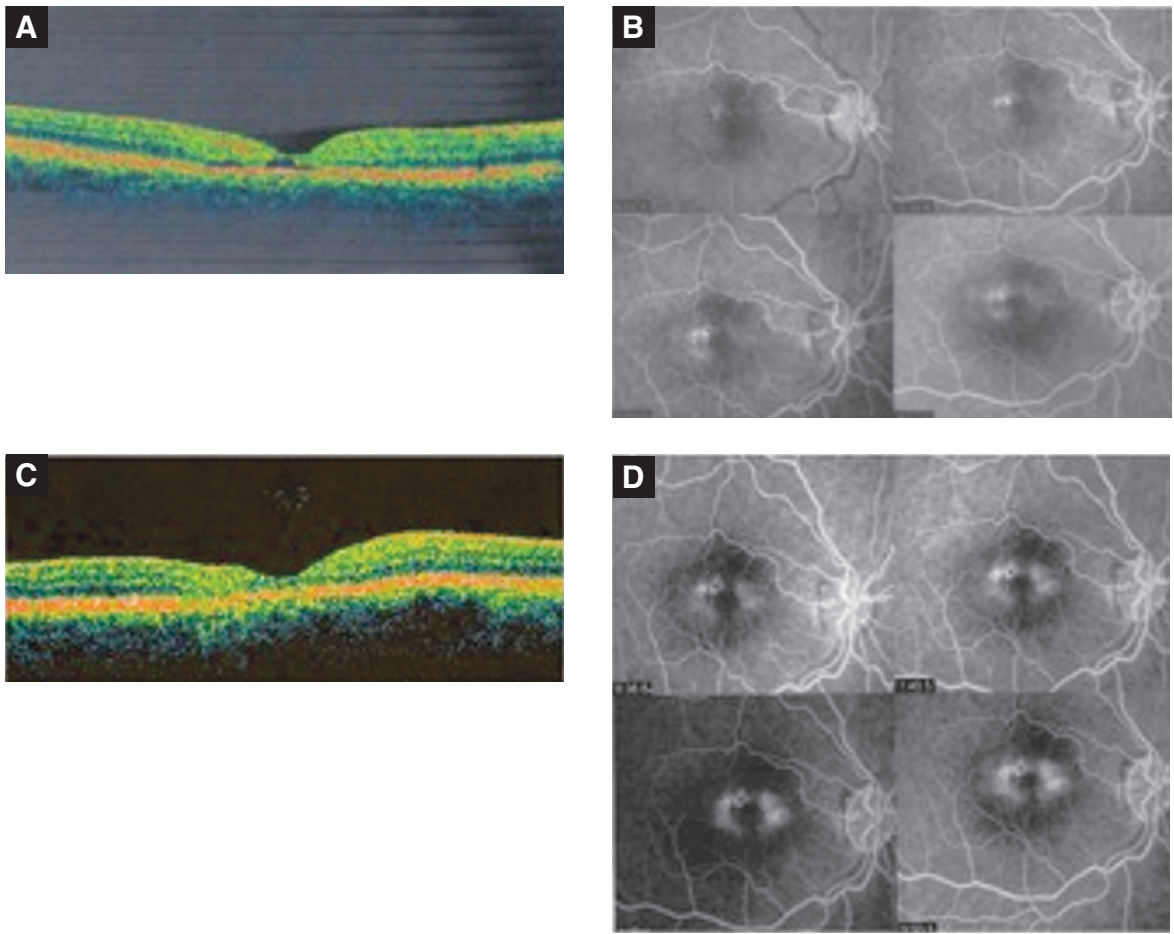

Figure 2 - (A) Six months after treatment the OCT reveals full regression of the foveal detachment.(B) A decrease in the fluorescein leakage can be seen in the right eye. (C) One year after a single-dose of bevacizumab, there is no foveal detachment observed by OCT. (D) There is an increase in the leakage detected by fluorescein angiography

\section{Discussion}

There is no approved treatment for patients with group 2 juxtafoveolar telangiectasia despite its poor prognosis. Watzke et al. ${ }^{(8)}$ studied the long-term follow-up of IJFT and observed that around two thirds of eyes decreased their vision to $20 / 70$ or worse specially on those with a central heavily pigmented RPE scar or a retinal neovascularization. Both Gass group $1 \mathrm{~A}$ and $2 \mathrm{~A}$ finally cause loss of central vision in most patients ${ }^{(8)}$.

Treatments have been proposed for group 2 patients such as laser photocoagulation, photodynamic therapy, transpupillary thermotherapy, triancinolone injection and recently bevacizumab intravitreous injection ${ }^{(2,6,7,9,10)}$. Since group 2 IJRFT is a retinal capillary disease with an increase in vascular permeability and occurrence of neovascularization in late stages, the use of an anti-VEGF seems to be very reasonable.

The use of an anti-VEGF for IJRFT it was described by Jorge et al. ${ }^{(7)}$ in a case complicated by juxtafoveolar subretinal neovascularization. The visual acuity improved from 20/40 to 20/ 20 with an absence of leakage in the fluorescein angiography and a resolution of subretinal fluid observed with the OCT.

Maia Junior et al. ${ }^{(6)}$ reported 3 eyes with IJFRT and a foveal detachment. It was used a single dose of bevacizumab and observed a marked decrease in the foveal detachment with an improvement in the visual acuity in all eyes.

In this report it was observed a fully regression of serous detachment in the foveal area in a case of idiopathic juxtafoveolar telangiectasis after a single dose of intravitreous bevacizumab injection with no recurrence of the serous detachment after one year of follow-up. The long term efficacy and effects in the retina should be evaluated with further studies.

\section{RefERENCES}

1. Gass JD, Oyakawa RT. Idiopathic juxtafoveolar retinal telangiectasis. Arch Ophthalmol. 1982;100(5):769-80.
2. Gass JD, Blodi BA. Idiopathic juxtafoveolar retinal telangiectasis. Up date of classification and follow-up study. Ophthalmology. 1993;100(10):1536-46.

3. Yannuzzi LA, Bardal AM,Freund KB, Chen KJ, Eandi CM, Blodi B. Idiopathic macular telangiectasia. Arch Ophthalmol. 2006;124(4):450-60.

4. Chopdar A. Retinal telangiectasis in adults: fluorescein angiographic findings and treatment by argon laser. $\mathrm{Br} \mathrm{J}$ Ophthalmol. 1978;62(4):243-50.

5. Engelbrecht NE, Aaberg TM Jr, Sung J,Lewis ML. Neovascular membranes associated with idiopathic juxtafoveolar telangiectasis. Arch Ophthalmol. 2002;120(3):320-4.

6. Maia OO Jr, Bonanomi MT, Takahashi WY, Nascimento VP,Takahashi BS. Intravitreal bevacizumab for foveal detachment in idiopathic perifoveal telangiectasia. Am J Ophthalmol. 2007;144(2):296-9.

7. Jorge R, Costa RA, Calucci D, Scott IU. Intravitreal bevacizumab (Avastin) associated with the regression of subretinal neovascularization in idiopathic juxtafoveolar retinal telangiectasis. Graefes Arch Clin Exp Ophthalmol. 2007;245(7):1045-8.

8. Watzke RC, Klein ML, Folk JC, Farmer SG, Munsen RS, Champfer RJ, et al. Long-term juxtafoveal retinal telangiectasia. Retina. 2005;25(6):727-35.

9. Potter MJ,Szabo SM, Sarraf D, Michels R,Schmidt-Erfurth U.Photodynamic therapy for subretinal neovascularization in type $2 \mathrm{~A}$ idiopathic juxtafoveolar telangiectasis. Can J Ophthalmol. 2006;41(1):34-7.

10. Shukla D, Singh J, Kolluru CM, Kim R, Namperumalsamy P. Transpupillary thermotherapy for subfoveal neovascularization secondary to group 2A idiopathic juxtafoveolar telangiectasis. Am J Ophthalmol. 2004;138(1):147-9. Comment in Am J Ophthalmol. 2005;139(3):577-8; author reply 578.

\section{Corresponding author:}

Paulo Escarião, MD, MBA

Altino Ventura Foundation - Department of Ophthalmology

170, Soledade St - CEP: 50040-070 - Recife(PE), Brazil

Tel.: (81) 3302-4300

Email: phescariao@hotmail.com 